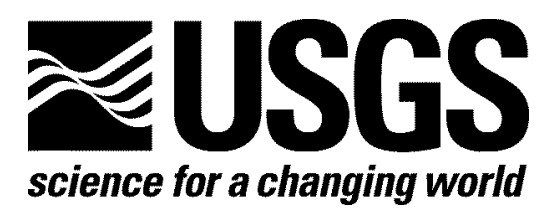

\title{
Micropaleontology of Selected Wells and Seismic Shot Holes, Northern Alaska
}

By Michael B. Mickey ${ }^{1}$, Hideyo Haga', and Kenneth J. Bird ${ }^{2}$

Open-File Report 2006-1055

U.S. Department of the Interior U.S. Geological Survey

1. Micropaleo Consultants, Encinitas, California

2. U.S. Geological Survey, Menlo Park, California 


\section{U.S. Department of the Interior \\ Gale A. Norton, Secretary}

\section{U.S. Geological Survey \\ P. Patrick Leahy, Acting Director}

U.S. Geological Survey, Menlo Park, California 2006

For product and ordering information:

World Wide Web: http://www.usgs.gov/pubprod

Telephone: 1-888-ASK-USGS

For more information on the USGS - the Federal source for science about the Earth,

its natural and living resources, natural hazards, and the environment:

World Wide Web: http://www.usgs.gov

Telephone: 1-888-ASK-USGS

Any use of trade, product, or firm names is for descriptive purposes only and does not imply endorsement by the U.S. Government.

Although this report is in the public domain, permission must be secured from the individual copyright owners to reproduce any copyrighted material contained within this report. 


\section{Contents}

Introduction and Summary

Background

Current Study

Distribution Charts

Data Sheets

Diversity Graphs

Reports

Seismic Shot Hole Samples

Acknowledgements

References Cited

\section{Figures}

1. Map showing locations of wells and correlation sections

2. Map showing seismic line and shot hole locations

3. Microfossil zonation scheme, stratigraphy, and ages

Well folder: Charts of microfossil abundance for each of 49 wells

W ell folder: Graphs of microfossil diversity for each of 49 wells

\section{Tables}

1. Summary listing of wells and seismic lines

2. Conversion of microfossil relative abundance to numerical abundance

W ell folder: Microfossil data sheets for each of 49 wells

3. Table of seismic shot hole paleontology

\section{Reports}

Well folder: Interpretive report for each of 49 wells

\section{Plates}

1. Correlation section B-1 of selected wells

2. Correlation section B-2 of selected wells

3. Correlation section B-3 of selected wells 


\title{
Micropaleontology of Selected Wells and Seismic Shot Holes, Northern Alaska
}

\author{
By Michael B. Mickey, Hideyo Haga, and Kenneth J. Bird
}

\section{Introduction and Summary}

This report provides micropaleontologic data (foraminifera, pollen, spores, and microplankton) and interpretations of the rocks penetrated by 49 wells and 3,134 seismic shot holes distributed among 73 seismic lines (figs. 1, 2; table 1). All shot holes and 30 wells are located within the National Petroleum Reserve in Alaska (NPRA); the remaining 19 wells are located adjacent to the NPRA. The biostratigraphic zonation scheme, stratigraphy, and geologic ages followed in this study are summarized in figure 3 . This update brings paleontologic analyses performed at various times over several decades to a current, unified set of interpretations that benefit from the evolution of northern Alaska biostratigraphic understanding developed during the past 33-years by Mickey and Haga.

For each well, paleontologic information includes microfossil distribution charts, data spreadsheets, diversity graphs, and interpretive reports describing age and environments of deposition. Three biostratigraphic well-correlation sections that relate Chukchi Sea wells to onshore northwestern NPRA wells are also included. For all analyzed seismic shot hole samples, foraminiferal age and environmental interpretations are provided; palynological interpretations are provided only for those shot hole samples collected and analyzed after 1976, a little less than half of the total number of samples.

\section{Background}

All wells in this report were analyzed and reported on in earlier times. Those wells in the NPRA, with the exception of the Brontosaurus well, were studied as part of the 1974-1981 government program (Gryc, 1988). Summaries of those interpretations are provided in tabular form by Witmer, Haga, and Mickey (1981) and Witmer, Mickey, and Haga (1981) and in graphical form by Magoon and others (1988). Wells outside of the NPRA were studied on an individual and sometimes proprietary basis; only some of the reports are available in the public well files available from the Alaska Oil and Gas Conservation Commission, Anchorage, or from the Department of the Interior Minerals Management Service, Anchorage.

Paleontologic reports of seismic shot hole samples collected during the 1974 to 1981 NPRA program were made publicly available in 1981 (Gibson and Bowsher, 1981). Analyses of shot hole samples from earlier surveys (1947-1949) have not previously been publicly available. Those samples were processed only for foraminifera and the slides are presently archived at the Alaska Geologic Materials Center in Eagle River. 


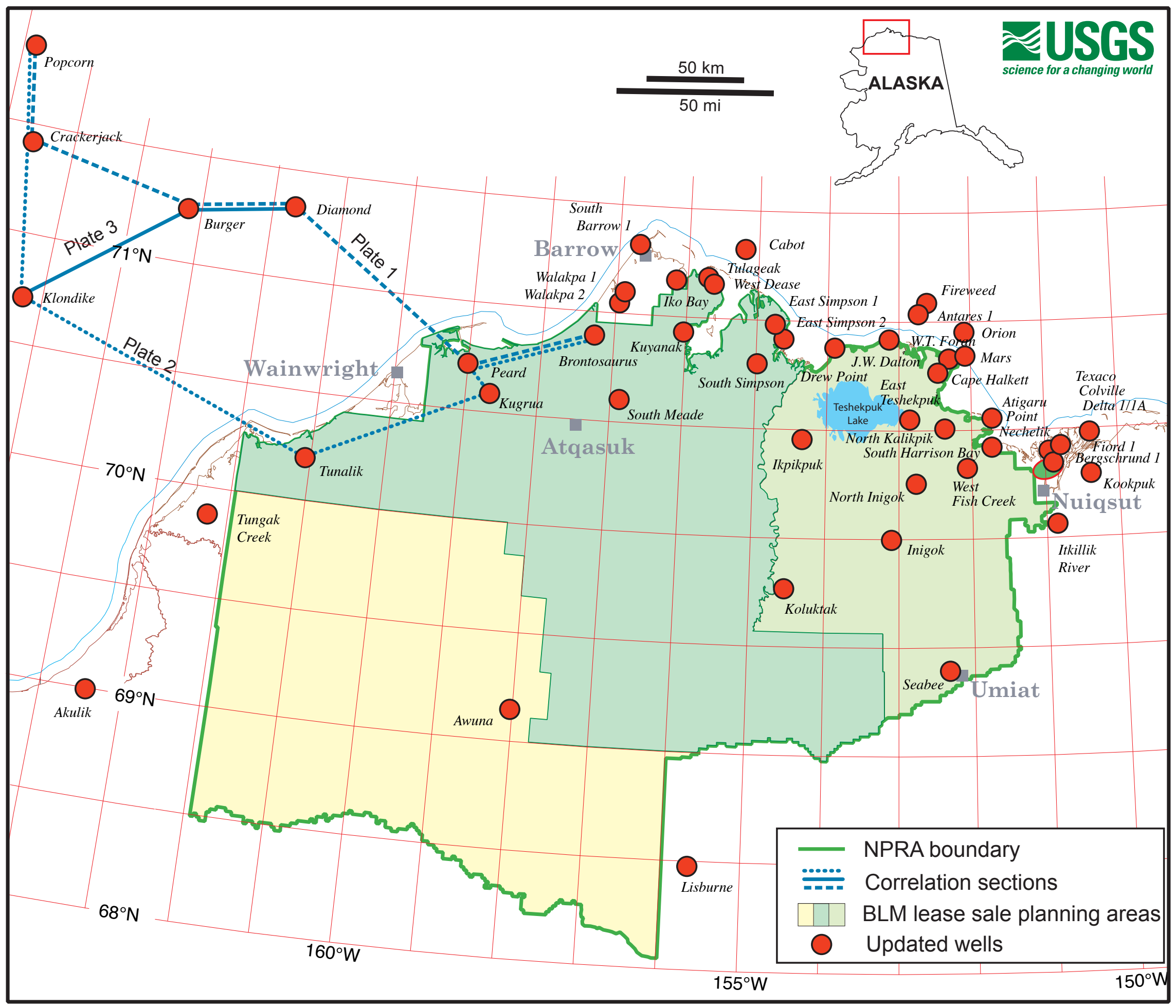

Figure 1. Location of wells with updated paleontology and well-correlation sections. 


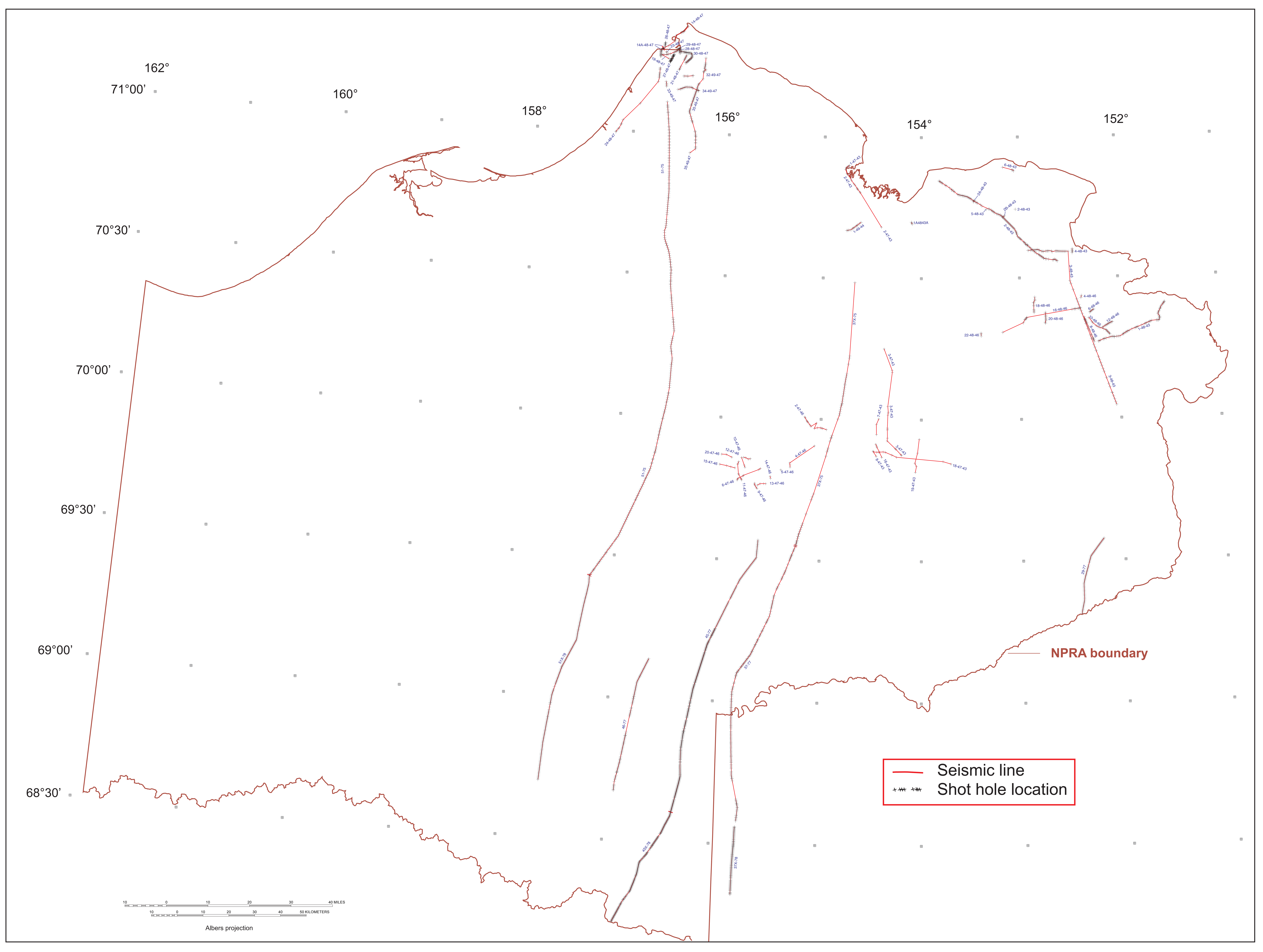

Figure 2. Map showing location of seismic lines and shot holes with micropaleontology. 
Table 1. Summary listing of wells and seismic lines with shot hole paleontology considered in this report. See figures 1 and 2 for locations.

\begin{tabular}{|c|c|c|c|c|c|c|c|}
\hline & WELLS & $\begin{array}{l}\text { DISTRIBUTION } \\
\text { CHARTS (.PDF) }\end{array}$ & \begin{tabular}{|c|} 
DATA \\
SHEETS \\
$(. X L S)$
\end{tabular} & $\begin{array}{l}\text { DIVERSITY } \\
\text { GRAPHS } \\
\text { (.PDF) }\end{array}$ & $\begin{array}{l}\text { REPORT } \\
\text { (.PDF) }\end{array}$ & SEISN & IIC LINES \\
\hline 1 & Akulik & $\mathrm{X}$ & $\mathrm{X}$ & $\mathrm{X}$ & $\mathrm{X}$ & \begin{tabular}{|l|}
$1-47$ \\
\end{tabular} & $26-48$ \\
\hline $2 \mid$ & Antares 1 (OCS 280-1) & $\mathrm{X}$ & $\mathrm{X}$ & $\mathrm{X}$ & $\mathrm{X}$ & $2-47$ & $27-48$ \\
\hline 3 . & Atigaru Point & $\mathrm{X}$ & $\mathrm{X}$ & $\mathrm{X}$ & $\mathrm{X}$ & $3-47$ & $28-48$ \\
\hline$\left.4\right|_{1}$ & Awuna & $\mathrm{X}$ & $\mathrm{X}$ & $\mathrm{X}$ & $\mathrm{X}$ & $4-47$ & $29-48$ \\
\hline $5 \mid 1$ & Bergschrund 1 & $\mathrm{X}$ & $\mathrm{X}$ & $\mathrm{X}$ & $\mathrm{X}$ & $5-47$ & $30-48$ \\
\hline $6 \mid 1$ & Brontosaurus & $\mathrm{X}$ & $\mathrm{X}$ & $\mathrm{X}$ & $\mathrm{X}$ & $6-47$ & $1-49$ \\
\hline $7 \mid 1$ & Burger (OCS 1413) & $\mathrm{X}$ & $\mathrm{X}$ & $\mathrm{X}$ & $\mathrm{X}$ & $7-47$ & $1 \mathrm{X}-1-49$ \\
\hline $8 \mid c$ & Cabot (OCS 0742) & $\mathrm{X}$ & $\mathrm{X}$ & $\mathrm{X}$ & $\mathrm{X}$ & $8-47$ & $2 \mathrm{X}-1-49$ \\
\hline 9 & Cape Halkett & $\mathrm{X}$ & $\mathrm{X}$ & $\mathrm{X}$ & $\mathrm{X}$ & $9-47$ & $3 \mathrm{X}-1-49$ \\
\hline $10 \mid$ & Colville Delta 1/1A & $\mathrm{X}$ & $\mathrm{X}$ & $\mathrm{X}$ & $\mathrm{X}$ & $10-47$ & $5 X-1-49$ \\
\hline 11 [ & Crackerjack (OCS 1320) & $\mathrm{X}$ & $\mathrm{X}$ & $\mathrm{X}$ & $\mathrm{X}$ & $11-47$ & 5W-R-1-49 \\
\hline 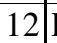 & Diamond (OCS 0996) & $\mathrm{X}$ & $\mathrm{X}$ & $\mathrm{X}$ & $\mathrm{X}$ & $12-47$ & $32-49$ \\
\hline 13 | 1 & Drew Point & $\mathrm{X}$ & $\mathrm{X}$ & $\mathrm{X}$ & $\mathrm{X}$ & $13-47$ & $33-49$ \\
\hline $14 \mid 1$ & East Simpson 1 & $\mathrm{X}$ & $\mathrm{X}$ & $X$ & $\mathrm{X}$ & $14-47$ & $34-39$ \\
\hline 15 & East Simpson 2 & $\mathrm{X}$ & $\mathrm{X}$ & $\mathrm{X}$ & $\mathrm{X}$ & $15-47$ & $35-49$ \\
\hline 16 & East Teshekpuk & $\mathrm{X}$ & $\mathrm{X}$ & $\mathrm{X}$ & $\mathrm{X}$ & $16-47$ & $29 X-77$ \\
\hline 17 | 1 & Fiord 1 & $\mathrm{X}$ & $\mathrm{X}$ & $\mathrm{X}$ & $\mathrm{X}$ & $18-47$ & $37-77$ \\
\hline 18 & Fireweed (OCS 0267) & $\mathrm{X}$ & $\mathrm{X}$ & $\mathrm{X}$ & $\mathrm{X}$ & $19-47$ & $37 \mathrm{X}-75$ \\
\hline 19 & Iko Bay & $\mathrm{X}$ & $\mathrm{X}$ & $\mathrm{X}$ & $\mathrm{X}$ & $20-47$ & $37 \mathrm{X}-78$ \\
\hline 20 & Ikpikpuk & $\mathrm{X}$ & $\mathrm{X}$ & $X$ & $\mathrm{X}$ & $\mathrm{R}$ ? & $45-77$ \\
\hline $21 \mid \mathrm{I} \quad r$ & Inigok & $\mathrm{X}$ & $\mathrm{X}$ & $\mathrm{X}$ & $\mathrm{X}$ & $1-\mathrm{A}-48$ & $45 X-78$ \\
\hline $22 \mid 1$ & Itkillik River Unit & $\mathrm{X}$ & $\mathrm{X}$ & $X$ & $\mathrm{X}$ & $2 \mathrm{~A}-\mathrm{B}-48$ & $46-77$ \\
\hline 23. & J.W. Dalton & $\mathrm{X}$ & $\mathrm{X}$ & $\mathrm{X}$ & $\mathrm{X}$ & $2 \mathrm{~A}-\mathrm{C}-48$ & $51-75$ \\
\hline $24 \mid 1$ & Klondike (OCS 1482) & $\mathrm{X}$ & $\mathrm{X}$ & $\mathrm{X}$ & $\mathrm{X}$ & 2A-D-48 & $51 X-78$ \\
\hline 25 & Koluktak & $\mathrm{X}$ & $\mathrm{X}$ & $X$ & $\mathrm{X}$ & $2 \mathrm{~A}-2-48$ & \\
\hline 26 & Kookpuk & $\mathrm{X}$ & $\mathrm{X}$ & $\mathrm{X}$ & $\mathrm{X}$ & 2B-48 & \\
\hline $27 \mid 1$ & Kugrua & $\mathrm{X}$ & $\mathrm{X}$ & $X$ & $\mathrm{X}$ & R-1-17-48 & \\
\hline $28 \mid 1$ & Kuyanak & $\mathrm{X}$ & $\mathrm{X}$ & $\mathrm{X}$ & $\mathrm{X}$ & $1-48$ & \\
\hline 29 & Lisburne & $\mathrm{X}$ & $\mathrm{X}$ & $\mathrm{X}$ & $\mathrm{X}$ & $2-48$ & \\
\hline $30 \mid 1$ & Mars (OCS 0302) & $\mathrm{X}$ & $\mathrm{X}$ & $\mathrm{X}$ & $\mathrm{X}$ & $3-48$ & \\
\hline $31 \mid 1$ & Nechelik & $\mathrm{X}$ & $\mathrm{X}$ & $X$ & $\mathrm{X}$ & $4-48$ & \\
\hline $32 \mid 1$ & North Inigok & $\mathrm{X}$ & $\mathrm{X}$ & $\mathrm{X}$ & $\mathrm{X}$ & $5-48$ & \\
\hline 33 | & North Kalikpik & $\mathrm{X}$ & $\mathrm{X}$ & $\mathrm{X}$ & $\mathrm{X}$ & $6-48$ & \\
\hline $34 \mid$ & Orion (OCS 0804) & $\mathrm{X}$ & $\mathrm{X}$ & $\mathrm{X}$ & $\mathrm{X}$ & $8-48$ & \\
\hline $35[1$ & Peard & $\mathrm{X}$ & $X$ & $X$ & $\mathrm{X}$ & $10-48$ & \\
\hline $36 \mid 1$ & Popcorn (OCS 1275) & $\mathrm{X}$ & $\mathrm{X}$ & $\mathrm{X}$ & $\mathrm{X}$ & $11-48$ & \\
\hline 37 & Seabee & $\mathrm{X}$ & $\mathrm{X}$ & $\mathrm{X}$ & $\mathrm{X}$ & $12-48$ & \\
\hline $38: 5$ & South Barrow 1 & $\mathrm{X}$ & $\mathrm{X}$ & $\mathrm{X}$ & $\mathrm{X}$ & $13-48$ & \\
\hline $39:$ & South Harrison Bay & $\mathrm{X}$ & $\mathrm{X}$ & $\mathrm{X}$ & $\mathrm{X}$ & $14-48$ & \\
\hline $40: 5$ & South Meade & $\mathrm{X}$ & $\mathrm{X}$ & $\mathrm{X}$ & $\mathrm{X}$ & $14 \mathrm{~A}-48$ & \\
\hline 41 s & South Simpson & $\mathrm{X}$ & $\mathrm{X}$ & $\mathrm{X}$ & $\mathrm{X}$ & $16-48$ & \\
\hline 42 & Tulageak & $\mathrm{X}$ & $\mathrm{X}$ & $X$ & $\mathrm{X}$ & $17-48$ & \\
\hline $43{ }^{2}$ & Tunalik & $\mathrm{X}$ & $\mathrm{X}$ & $\mathrm{X}$ & $\mathrm{X}$ & $18-48$ & \\
\hline $44[7$ & Tungak Creek & $\mathrm{X}$ & $\mathrm{X}$ & $\mathrm{X}$ & $\mathrm{X}$ & $19-48$ & \\
\hline 45 & Walakpa 1 & $\mathrm{X}$ & $\mathrm{X}$ & $\mathrm{X}$ & $\mathrm{X}$ & $20-48$ & \\
\hline 46 & Walakpa 2 & $\mathrm{X}$ & $\mathrm{X}$ & $\mathrm{X}$ & $\mathrm{X}$ & $21-48$ & \\
\hline 47 & West Dease & $\mathrm{X}$ & $\mathrm{X}$ & $\mathrm{X}$ & $\mathrm{X}$ & $22-48$ & \\
\hline 48 & West Fish Creek & $\mathrm{X}$ & $\mathrm{X}$ & $\mathrm{X}$ & $\mathrm{X}$ & $23-48$ & \\
\hline 49 & W.T. Foran & $\mathrm{X}$ & $\mathrm{X}$ & $\mathrm{X}$ & $\mathrm{X}$ & $24-48$ & \\
\hline
\end{tabular}




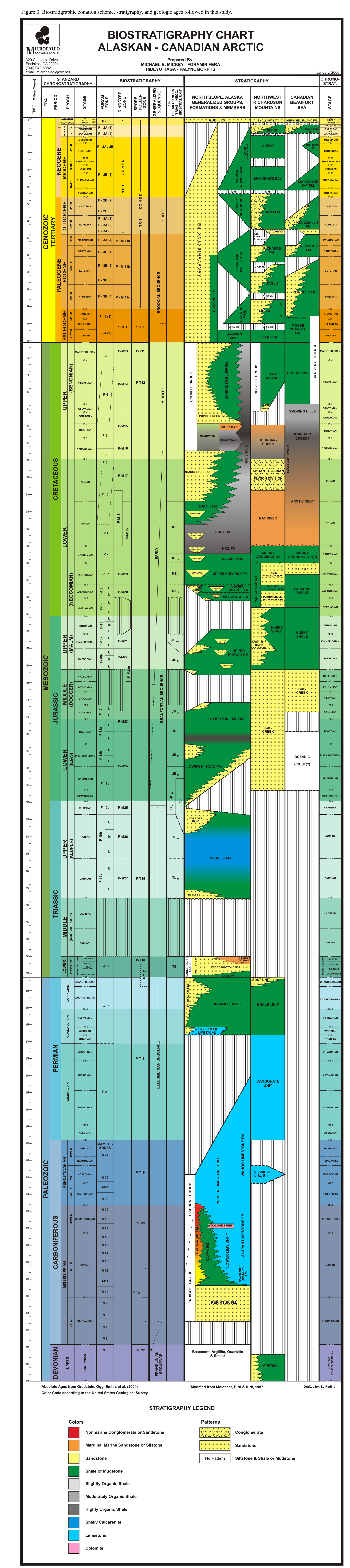




\section{Current Study}

In the current study, no new well samples were processed or analyzed. Data from existing paper copy records were transcribed and age interpretations were reviewed and, in some cases, reinterpreted. Three types of displays were created from the transcribed data: distribution charts, data sheets, and diversity graphs. Distribution charts show relative microfossil abundances plotted against depth. Data sheets show relative abundances converted to numerical abundances according to the scheme in table 2 and plotted against depth. Diversity graphs show total microfossil abundance and number of species (diversity). A narrative report for each well provides interpreted ages and environments of deposition. Also, for the five wells located in the Chukchi Sea, biostratigraphic correlation charts (plates 1-3) were created that tie those wells to selected onshore wells in northwestern NPRA.

Data from existing paper copy records of seismic shot hole samples collected from 1975 to 1978 were also transcribed. Foraminiferal slides from seismic shot hole samples collected from 1947 to 1949 were newly analyzed and interpreted at the Eagle River Geologic Materials Center, Alaska.

The data and results of this study are organized in the following way. For each of the 49 wells, a separate folder is provided, within which relevant files of distribution charts, data sheets, diversity graphs, and reports are located. All seismic shot hole information is provided in a single Excel file (table 3) with multiple worksheets.

Table 2. Explanation of conversion of microfossil relative abundances to numerical midpoint values necessary for creating diversity plots.

\begin{tabular}{|c|c|c|c|c|}
\hline \multicolumn{5}{|c|}{ Foraminifera } \\
\hline \multicolumn{2}{|c|}{ RELATIVE ABUNDANCE } & \multicolumn{3}{|c|}{ NUMERICAL ABUNDANCE } \\
\hline Symbol & Descriptor & Range & Mid-Point* & Mid-Point Formula \\
\hline $\mathrm{X}$ & Very Rare & 1 & 1 & $(1+1) / 2$ \\
\hline $\mathrm{R}$ & Rare & $2-4$ & 3 & $(2+4) / 2$ \\
\hline $\mathrm{F}$ & Frequent & $5-25$ & 15 & $(5+25) / 2$ \\
\hline $\mathrm{C}$ & Common & $26-100$ & 63 & $(26+100) / 2$ \\
\hline A & Abundant & $101-1000$ & 550 & $(101+1000) / 2$ \\
\hline $\mathrm{P}$ & Prolific & $1001-5000$ & 3000 & $(1001+5000) / 2$ \\
\hline \multicolumn{5}{|c|}{ Palynology (spore, pollen, microplankton) } \\
\hline \multicolumn{2}{|c|}{ RELATIVE ABUNDANCE } & \multicolumn{3}{|c|}{ NUMERICAL ABUNDANCE } \\
\hline Symbol & Descriptor & Range & Mid-Point* & Mid-Point Formula \\
\hline $\mathrm{X}$ & Very Rare & 1 & 1 & $(1+1) / 2$ \\
\hline $\mathrm{R}$ & Rare & $2-5$ & 3 & $(2+5) / 2$ \\
\hline $\mathrm{F}$ & Frequent & $6-15$ & 10 & $(6+15) / 2$ \\
\hline $\mathrm{C}$ & Common & $16-30$ & 23 & $(16+30) / 2$ \\
\hline A & Abundant & $31-500$ & 265 & $(31+500) / 2$ \\
\hline $\mathrm{P}$ & Prolific & $501-5000$ & 2750 & $(501+5000) / 2$ \\
\hline
\end{tabular}

* Values rounded down to nearest integer. 


\section{Distribution Charts}

Typically for each well there is one palynology distribution chart $(\mathrm{P})$ and one to as many as four foraminiferal distribution charts $(\mathrm{F})$, depending on number of samples analyzed. All are in Adobe Acrobat ${ }^{\circledR}$ pdf-format and are identified in the well folder by the label "C-(well name).pdf". These charts show microfossil occurrence and relative abundance by well depth in feet. The foraminiferal charts also include observed occurrences of radiolaria (RADS.), miscellaneous other microfossils, shell fragments, and distinctive rock, mineral, and hydrocarbon occurrences. Also included on the plots are interpreted age, stage, zone and environment of deposition and faunal statistics.

\section{Data Sheets}

Data sheets show numerical (mid-point) abundance converted from relative abundance according to the scheme shown in table 2. Data sheets are in Microsoft Excel ${ }^{\circledR}$ format and are identified in the well folder by the label "S-(well name).xls". All of the microfossil and other components recorded on the distribution charts are incorporated here. For selected wells, a brief description of the lithology observed in the processed foraminiferal sample is included.

\section{Diversity Graphs}

Using the numerical values reported in the data sheets, graphs were created showing diversity (number of species) and total abundance of foraminifera, spore-pollen, and microplankton, respectively, for each well. These plots, labeled High Resolution Biostratigraphy Plots, Foraminifera/Palynomorphs, are identified in the well folder by the label "DV-(well name).pdf”.

\section{Reports}

For each well, a narrative report in is included. This report typically provides a brief description of the number of samples analyzed, the processing and reporting procedures, and the results of the analysis. Results are presented in both abbreviated form - just depth and age - and more detailed form consisting of microfossil zone, a listing of distinctive microfossils, the interpreted environment of deposition, and a brief discussion. These reports are identified in the well folder by the label "R-(well name).pdf”.

\section{Seismic Shot Hole Samples}

Analyzed NPRA seismic shot hole samples (total 3,134) are from the exploration program of 1946-1953 conducted by the U.S. Navy and from the program of 1974-1981, initially conducted by the U.S. Navy and later, by the U.S. Department of the Interior. Shot hole samples, typically collected at depths of about $100 \mathrm{ft}$ but some from as deep as $290 \mathrm{ft}$, provide information on near-surface geologic units where exposures are poor to 
nonexistent. The older set of shot hole samples $(1,710)$ consists only of foraminiferal slides on file at the Alaska Geologic Materials Center in Eagle River, Alaska. Those slides were analyzed by Mickey in 2001 and 2002 at Eagle River. No comparable palynologic slides for those samples exist. The newer set of shot hole samples $(1,424)$ includes both foraminiferal and palynologic analyses performed on contract to the U.S. Geological Survey during the exploration program of 1974-1981 (Gibson and Bowsher, 1981). Fossil checklists of these samples were reviewed and reinterpreted for this study. Shot hole details (seismic line and shot hole number, sample depth if available, and latitude-longitude location) and paleontologic interpretations are presented in table 52; seismic lines are located in figure 2. Location information has been lost for a number of the older U.S. Navy shot holes and has been left blank on table 3.

\section{Acknowledgements}

This compilation was facilitated by behind-the-scene data retrieval, plotting, drafting, and general organizational efforts of Megan Simpson, Zenon Valin, and Nick Zihlman of the U.S. Geological Survey, and Edward Padilla of Miropaleo Consultants. This report has benefited from the reviews of Mary McGann and Margaret Keller.

\section{References Cited}

Gibson, H.A., and Bowsher, A.L., 1981, Availability of foraminifera and palynomorph reports from shot hole samples of National Petroleum Reserve in Alaska: U. S. Geological Survey Open-File Report 81-1340, 3 p.

Gradstein, F.M., Ogg, J.G., and Smith, A.G., eds., 2004, A geologic time scale 2004, Cambridge University Press, 589 p.

Gryc, G., ed., 1988, Geology and exploration of the National Petroleum Reserve in Alaska, 1974 to 1982, U.S. Geological Survey Professional Paper 1399, 940 p.

Magoon, L.B., Bird, K.J., Claypool, G.E., Weitzman, D.E., and Thompson, R.H., 1988, Organic geochemistry, hydrocarbon occurrence, and stratigraphy of governmentdrilled wells, North Slope, Alaska, in Gryc, G., ed., Geology and exploration of the National Petroleum Reserve in Alaska, 1974 to 1982, U.S. Geological Survey Professional Paper 1399, p. 483-487.

Witmer, R.J., Haga, H., and Mickey, M.B., 1981, Biostratigraphic report of thirty-three wells drilled from 1975 to 1981 in the National Petroleum Reserve in Alaska: U. S. Geological Survey Open-File Report 81-1166, 50 p.

Witmer, R.J., Mickey, M.B., and Haga, H., 1981, Biostratigraphic correlations of selected test wells of National Petroleum Reserve in Alaska: U.S. Geological Survey Open-File Report 81-1165, 89 p. 